Johanna A. A. Bos • Bas van Geel •

Bert J. Groenewoudt • Roel C. G. M Lauwerier

\title{
Early Holocene environmental change, the presence and disappearance of early Mesolithic habitation near Zutphen (The Netherlands)
}

Received: 12 March 2004 / Accepted: 7 December 2004 / Published online: 27 October 2005

(C) Springer-Verlag 2005

\begin{abstract}
The Early Holocene landscape near Zutphen (The Netherlands) is reconstructed by means of microfossil, macroremain and bone analyses. In this area early Mesolithic sites were found on a river dune along a former river channel. AMS ${ }^{14} \mathrm{C}$ dating provided a detailed chronology for the sites and river channel deposits. Between ca. 9800-9600 B.P. open herbaceous vegetation was present on the river dunes. The residual channels were fringed by reed swamps and willow shrubs, with birch and poplar woodlands inland. During this period there are indications of natural or man-made burning of the reed swamp vegetation along the residual channel. Also trampling zones along the lake edge were more abundant. However, no archaeological sites were discovered in the vicinity. From ca. 9600 B.P. on, the area became more densely forested; willow, birch and poplar replaced the reed swamps along the residual channels, while pine colonised the river dunes. Archaeological finds show that early Mesolithic people inhabited the area between ca. 9400 and 9200 B.P. and between ca. 8900-8700 B.P. During the earlier period, records of Urtica, Plantago and coprophilous fungi may point to trampling and/ or eutrophication as a result of the presence of large herbivores and people along the channel shores. After ca. 8700 B.P. people probably left the area when open water was no longer available in the vicinity.
\end{abstract}

Keywords Preboreal · Mesolithic · Palynology · Macroremains · Palaeoenvironment · The Netherlands

J. A. A. Bos $(\bowtie) \cdot$ B. van Geel

Institute for Biodiversity and Ecosystem Dynamics, Research Group Paleoecology and Landscape Ecology, Universiteit van Amsterdam,

Kruislaan 318, NL-1098 SM Amsterdam, The Netherlands e-mail: hanneke.bos@falw.vu.nl

B. J. Groenewoudt · R. C. G. M. Lauwerier

National Service for Archaeological Heritage

in The Netherlands (ROB),

P.O. Box 1600, NL-3800 BP Amersfoort, The Netherlands

\section{Introduction}

During the Mesolithic the principal means of subsistence were hunting, fishing and gathering. These activities had a supposedly small and local impact on the vegetation, with little effect upon vegetation composition and pollen deposition and thus easily overlooked in pollen diagrams. To assess the effect of human activity on the environment, high-resolution studies (e.g. Simmons 1993; Hicks 1993; Day 1993; Day and Mellars 1994; Simmons et al. 1989; Bos and Janssen 1996; Bos and Urz 2003) are needed for small-scale changes in vegetation or occupation phases to be detectable. Furthermore, the detection of human-induced small local vegetation changes is dependent on the distance between the area of activity and the area from which the samples were derived (Kloss 1987a; Hicks 1993; Bos and Janssen 1996).

In order to gather information on the palaeo-environment of the early Mesolithic people that occupied the Zutphen-Ooijerhoek site, several sequences were collected for microfossil and macroremain analyses during archaeological excavations in 1999 and 2000. Preliminary results of palynological analysis of one of these sequences were published by Groenewoudt et al. (2001). The results of a more detailed study of microfossils, macroremains and environmental information from the archaeozoological material are presented and discussed below.

\section{Study area}

The Zutphen-Ooijerhoek site is located in the eastern Netherlands at the transition between an extensive coversand area in the east and the stream valley of the IJssel river in the west (Fig. 1). In the transitional zone between the area of sand and the IJssel valley, numerous river dunes that were formed during the late Weichselian and early Holocene are present. On one of these dunes, probably formed during the Younger Dryas stadial, a cluster of early Mesolithic sites was found (Fig. 2; Groenewoudt et al. 2001). During the Holocene a brown 


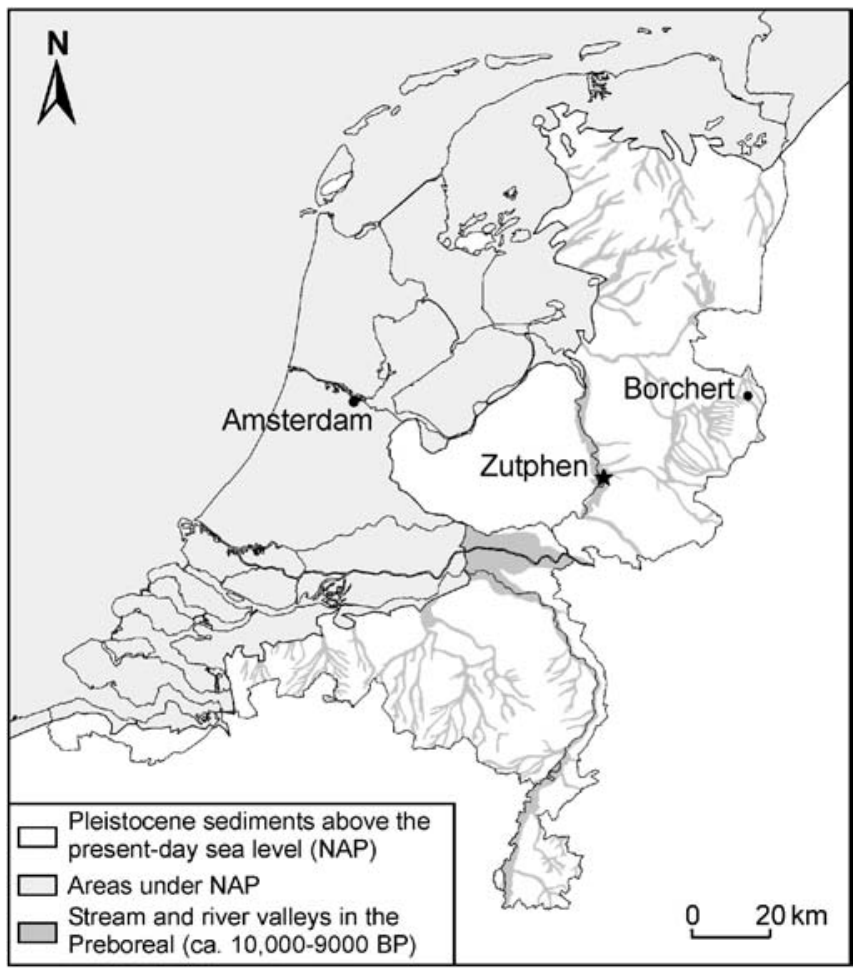

Fig. 1 Location of the Zutphen-Ooijerhoek site and other locations mentioned in the text. Pleistocene sediments above the present sealevel (NAP) and areas under the present sea-level are shown. Also shown are the stream and river valleys during the Preboreal (ca. 10,000-9000 B.P.). Data used are from Zagwijn (1986), van Es et al. (1988) and Spek (1996). Figure adapted from Groenewoudt et al. (2001)

forest soil developed in the dunal sand (Kooistra et al. 1999). The river dune was bordered on the southeast by an old ca. $200 \mathrm{~m}$ wide river valley, in which at present the river Ooijerhoeksche Laak is flowing.

During the early Holocene a river cut into the older river sediments (the Kreftenheye IV formation, Fig. 3) to a depth of $3 \mathrm{~m}$ and in an abandoned channel a Late Preboreal organic deposit was formed. During the Boreal and Atlantic periods, the river valley was partly filled in with a $1.5 \mathrm{~m}$ thick layer of fluvial deposits. Numerous thin lenses of peat and sand overlie each other indicating a dynamic environment with alternating processes of erosion and sedimentation (Fig. 3). During the Late Roman period or Middle Ages, the entire area was covered by an iron-rich clay layer that was deposited by the river IJssel. Due to occupation and agrarian activities, erosion of the dune occurred during the last two millenia. The entire river dune was later covered by a plaggen soil.

\section{Material and methods}

Archaeological sites

In 1999 and 2000 a number of Mesolithic sites were excavated completely (Q, A, H, and C, Fig. 2) and partly (B and K, Fig. 2), in a strip of the river dune up to a maximum distance of less than $60 \mathrm{~m}$ from a residual meander channel (Groenewoudt et al. 2001). About $200 \mathrm{~m}$ further away a seventh site (S) had already been excavated in 1988 (Verneau 1999). Also in 2000 the edge of the meander channel bordering the river dune was partly excavated (Fig. 2). In the lower part of the channel infill a concentration of stone artefacts, botanical and faunal remains was found. $\mathrm{A}^{14} \mathrm{C}$ date of $9410 \pm$ 40 B.P. was obtained from a partly charred piece of pine wood and led to further excavation of these sediments, which were designated site M. Also test sections were made from the dune across the valley (Fig. 2), but lack of time prevented the opening up of a broad area to a further depth.

\section{Botanical analysis}

At site $\mathrm{M}$, botanical samples were collected in metal boxes from the various cross-sections in the sediments of the residual channel fills, i.e. sequences I-VI (Fig. 2). Subsamples were taken from these boxes at short intervals for microfossil and macroremain analyses. Microfossil samples were prepared according to Faegri and Iversen (1989) with the addition of heavy liquid separation to remove minerogenic components. Sieving was done over a $215 \mu \mathrm{m}$ sieve. To estimate pollen concentrations Lycopodium spores were used (Stockmarr 1971). The pollen sum included trees, shrubs, Ericales (Calluna and Empetrum) and terrestrial herbs, and was in general $>400$.

The samples used for macroremain analyses varied between 10 and $23 \mathrm{ml}$, with an average of $17 \mathrm{ml}$. Plant macrofossils were recovered by washing the material over a 75-80 $\mu \mathrm{m}$ sieve. All material has been stored for future checking. Plant macroremain and pollen identifications were made by comparison with modern reference material. Pollen types in general refer to Moore et al. (1991) or to the Northwest European Pollen Flora (Punt et al. 19762003)

Combined pollen percentage and macroremain diagrams were constructed using the TILIA, TILIAGRAPH and TGVIEW computer programs (Grimm 1992). Taxa were arranged in basic ecological groups. Pollen types are displayed by curves, macroremains are displayed by histograms (total amounts), presence or abundance (+ present, ++ abundant and +++ very abundant)

A first screening of the microfossil subsamples from sequences I-VI showed that most deposits contained abundant Alnus (alder) pollen. This indicates that these sediments were deposited at least after ca. 8000 B.P. (compare van Geel et al. 1981) and are too young to be contemporaneous with the early Mesolithic sites. Only the lower $8 \mathrm{~cm}$ of the Zutphen-I sequence and the lower $47 \mathrm{~cm}$ of Zutphen-VI appeared to be older than ca. 8000 B.P. Both sequences showed an erosional hiatus at the top of the deposits. It turned out that only the Zutphen-VI sequence showed an Early Holocene age, while the Zutphen-I sequence could be dated to the Lateglacial. The Zutphen-VI sequence was analysed for pollen, spores and other microfossils at every $\mathrm{cm}$ between 30 and $77 \mathrm{~cm}$. Above $30 \mathrm{~cm}$ the samples were analysed every $5 \mathrm{~cm}$. Macrofossil samples were taken every $4 \mathrm{~cm}$.

\section{Zoological analysis}

All the early Mesolithic animal remains studied and a single human tooth originated from site $\mathrm{M}$ (Table 1). The material was collected in $50 \times 50 \mathrm{~cm}$ excavation squares of 5 to $15 \mathrm{~cm}$ depth by sieving the soil through a $3 \mathrm{~mm}$ screen. Most of the remains are well preserved and unburned; only ten small fragments are calcined. The remains were analysed and described according to the standard procedure of the National Service for Archaeological Heritage in The Netherlands (ROB) (Lauwerier 1997; Groenewoudt et al. 2001). The present study focuses on the ecological significance of the faunal remains. 
Fig. 2 Zutphen-Ooijerhoek. Schematic overview of the landscape showing the location of finds on the river dune $(\mathrm{Q}, \mathrm{A}$, $\mathrm{H}, \mathrm{C} \mathrm{B}$ and $\mathrm{K}$ ) and the concentration of artefacts in the residual meander channel $(\mathrm{M})$. Detail: at site $M$, the find contexts $1-6$ and the location of the botanical sequences I-VI are shown. At the lowest level of the meander infill, a large number of channels were revealed, the two oldest channels are displayed here (adapted from Groenewoudt et al. 2001)

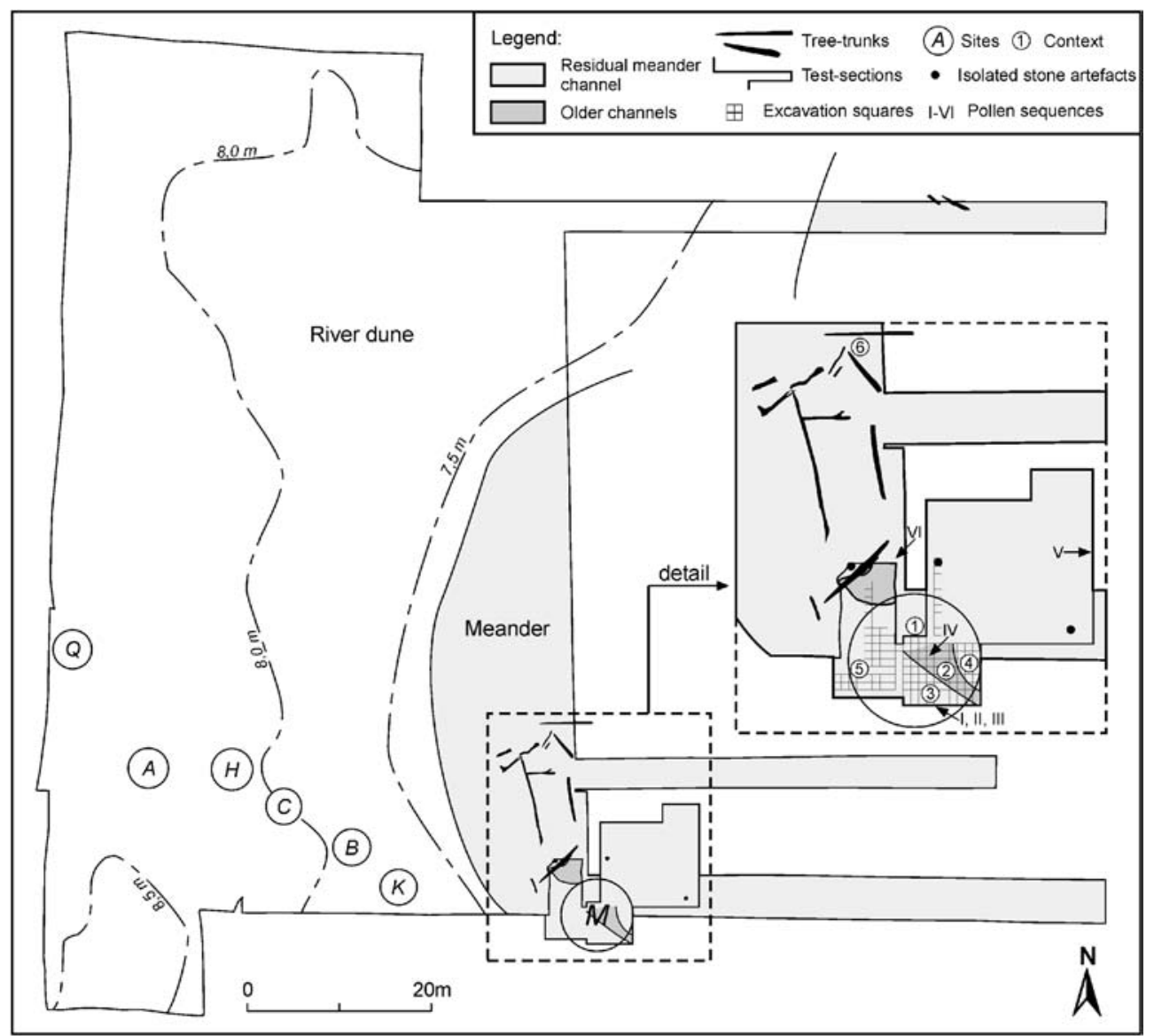

Fig. 3 Zutphen-Ooijerhoek. Simplified geological profile of the river dune and adjacent river valley (after Groenewoudt et al. 2001)

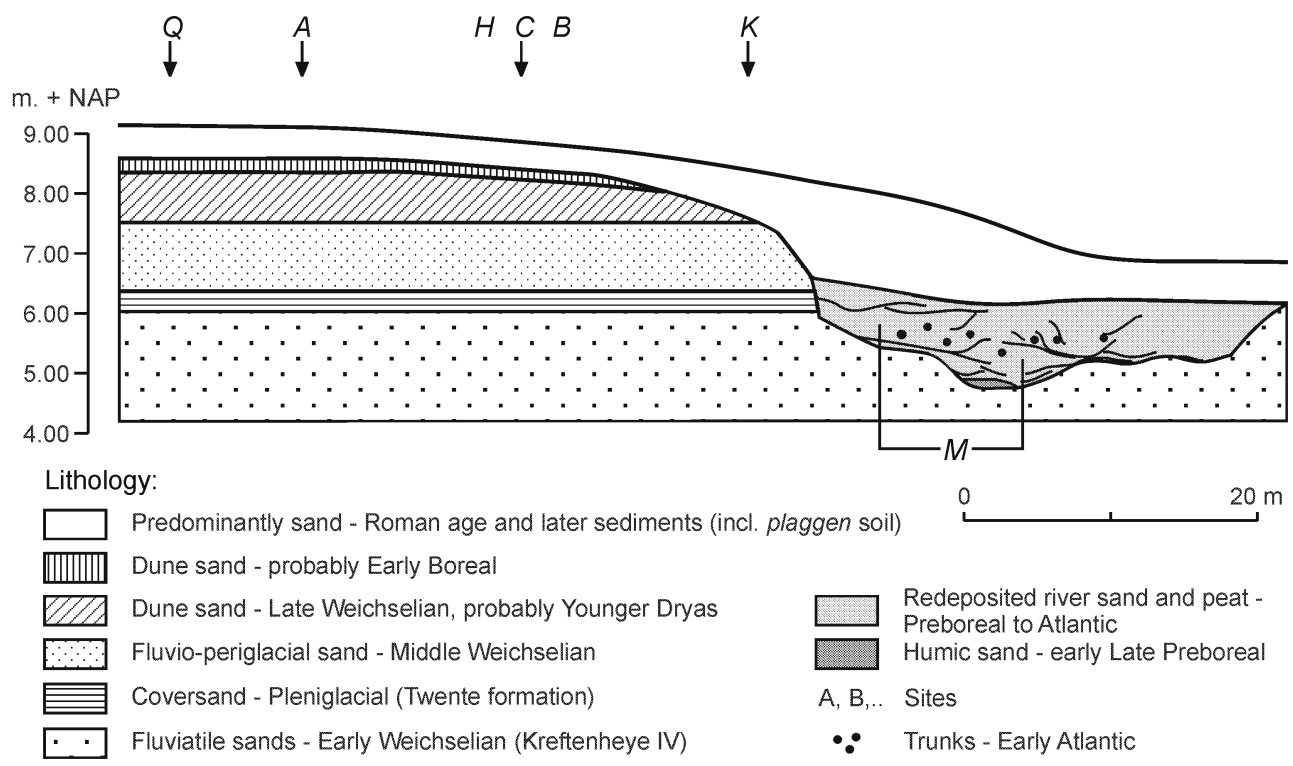

\section{Radiocarbon dating}

The radiocarbon dates for the Mesolithic sites on the river dune range between $9110 \pm 70$ B.P. and $8820 \pm 90$ B.P. (Groenewoudt et al. 2001, Table 2). A hazelnut sample from site $C$ gave a much more recent date of $7200 \pm 60$ B.P. (Table 2). Distinct concentrations of charcoal were encountered within the excavated area. Pinus charcoal from two of these concentrations revealed ages of $8400 \pm$
70 B.P. and $8300 \pm 70$ B.P. (Table 2), which are both more recent than the excavated sites.

Eleven samples were selected for radiocarbon dating from the organic material recorded in the residual channel infill at site $M$ (Table 2). A number of samples (Table 2) were selected because of traces of carving (samples 2000-2 and 2000-8), or because they were partly burnt, probably as a result of human activity (2000-1 
Table 1 The zoological remains from site M

\begin{tabular}{lcc}
\hline Zoological remains & Number & Weight in gr \\
\hline Mammals & 8 & 133.6 \\
Wild boar-Sus scrofa & 7 & 795.4 \\
Red deer-Cervus elaphus & 5 & 45.6 \\
Roe deer-Capreolus capreolus & 1 & 44.2 \\
Brown bear-Ursus arctos & 1 & 0.6 \\
Wild cat-Felis silvestris & 5 & 74.6 \\
Beaver-Castor fiber & 1 & 0.0 \\
Ground vole-Arvicola terrestris & 1 & 0.6 \\
Man-Homo sapiens & & \\
Mammals not identified & 9 & 36.7 \\
Large mammal & 17 & 7.1 \\
Medium mammal & 4 & 0.0 \\
Small rodent & 28 & 10.2 \\
Mammal & 1 & 0.2 \\
Birds & & \\
Bird-Aves indet & 1 & 0.0 \\
Fish & 1 & 0.2 \\
Roach-Rutilus rutilus & & \\
Pike-Esox lucius & 1 & 1149.0 \\
Molluscs & 91 & \\
Unio-Unio sp & & \\
Total &
\end{tabular}

and 2000-4), or to check if the material (2000-14) was contemporous with the artefacts (Groenewoudt et al. 2001).

Also from the Zutphen-VI botanical sequence four macroremain samples were analysed in order to collect material for ${ }^{14} \mathrm{C}$ AMS dating. Organic material reflecting atmospheric ${ }^{14} \mathrm{C}$ concentrations, such as seeds and fruits from terrestrial plants, was preferred, in order to reduce the likelihood of contamination by older or younger carbon (Marcenko et al. 1989; Törnqvist et al. 1992).

The radiocarbon samples presented here were bulk or AMS samples (respectively GrN or GrA, Table 2) dated at the AMS facility (CIO) in Groningen, The Netherlands. Radiocarbon dates were calibrated to calendar years using the CALIB 4.4 software program (Stuiver and Reimer 1993) and the INTCAL98 calibration curve (Stuiver et al. 1998). For the calibrated age range the $1 \sigma$ standard deviation was taken. All radiocarbon ages are expressed in conventional ${ }^{14} \mathrm{C}$ years B.P.

\section{Results}

Archaeological results

Most of the archaeological material recovered from the river dune was stone (i.e. flint), charcoal and charred hazelnut shells. At sites A and Q (Fig. 2), located furthest away from the meander, isolated concentrations of artefacts were found. The sites located closer to the meander showed a more or less continuous distribution of artefacts, in which dense clusters could be defined (Fig. 2: sites H, $\mathrm{C}, \mathrm{B}$ and $\mathrm{K}$ ). Almost all the sites had concentrations of charred hazelnut shells, presumably reflecting the location of surface hearths.

In the lower part of the meander infill (site M, Fig. 2) a concentration of stone artefacts, faunal remains (pieces of bone and antler) and large quantities of well-preserved botanical remains, including pieces of wood (Pinus, Corylus and Quercus), many hazelnuts and pine cones were found. The position of the organic artefacts was mainly restricted to the remnant of one of the many channels that showed up in the lowest level of the meander infill (context 2, Fig. 2). The artefacts from context 2 were concentrated in a channel that had been incised in river sand dating to the Weichselian and were ${ }^{14} \mathrm{C}$ dated to between $9390 \pm 30$ B.P. and $8720 \pm 60$ B.P. (Table 2). Some material was found in sandy channel sediments to the east of context 2 (context 4, Fig. 2) and to the west (context 3, Fig. 2). No bones were found in the area towards the river dune (context 5, Fig. 2). The archaeological finds at site $\mathrm{M}$ show that early Mesolithic people inhabited the area between ca. 9400 and 9200 B.P. and between 8900 and 8700 B.P. From contexts $1-5$ of site M, a total of 244 lithic artefacts were recovered. Of these 232 were flint artefacts together with 6 unworked pieces of flint, 2 fragments of grindstones, 2 fragments of a sandstone slab, a block and an unworked piece of other types of stone (Groenewoudt et al. 2001). All the stone artefacts were identified as early Mesolithic. On a number of artefacts traces of wear were found, which indicated a wide range of different activities, such as wood working (shaving of branches and twigs), the cutting of siliceous plant material, bone, fresh hide and possibly hunting (Groenewoudt et al. 2001).

From the upper part of the meander infill trunks of various trees (e.g., oak and alder) were encountered. One hewn oak gave a radiocarbon date of $7455 \pm 25$ B.P. (context 6, Fig. 2). Otherwise, no indication of human activity was found at that level.

\section{Zutphen-VI botanical sequence}

Based on changes in the forest composition and herbaceous vegetation the Zutphen-VI sequence can be subdivided into three parts (Figs. 4 and 5):

Between 77 and $44 \mathrm{~cm}$, high values of Betula pollen (40-65\%) and herbaceous taxa (20-45\%, especially Poaceae, Rumex acetosella and Artemisia) and low values of pine $(<20 \%)$ are recorded. Pollen concentrations in the basal sandy deposits are relatively low, but increase when the sediment becomes more organic at $70 \mathrm{~cm}$ and changes into sandy peat, and again when it changes into peat at $65 \mathrm{~cm}$ (Fig. 5). High percentages and concentrations of Betula pollen coincided with large numbers of macroremains. The shape of the Betula fruits and female catkin scales suggests that both Betula pubescens (downy birch) and B. pendula (silver birch) were present. However, since it was not possible to make a clear distinction between the species based on their pollen or macroremains, they were referred to as Betula sect. Albae. At $45 \mathrm{~cm}$ a charred Betula fruit was found. Furthermore, pollen of Populus (poplar) was recorded (up to 8\%). Higher values of Populus pollen coincided with occurrences of bud scales and catkin scales. Salix (willow) pollen was recorded at values of between 5-10\% and macroremains were abundantly present. Rhamnus (buckthorn) appeared slightly later.

The relatively high percentages and concentrations of Poaceae were caused by the presence of Phragmites australis (reed) in the vicinity of the sample site. Also at 
Table 2 Radiocarbon dates of the Zutphen-Ooijerhoek site. Calibrated using the CALIB 4.4 program (Stuiver and Reimer 1993). Samples 2000-8 and 2000-13 were rejected, based on deviating $\delta^{13} \mathrm{C}$ values. In general, the ages of the early Mesolithic artefacts at site M range between ca. 9400-9200 B.P. and between ca. 8900-
8700 B.P., with the exception of a few more recent dates with ages around 7450 B.P., related to sedimentation during the Atlantic period. The four ${ }^{14} \mathrm{C}$ samples from the Zutphen VI sequence revealed ages between $9760 \pm 70$ B.P. and $9430 \pm 50$ B.P.

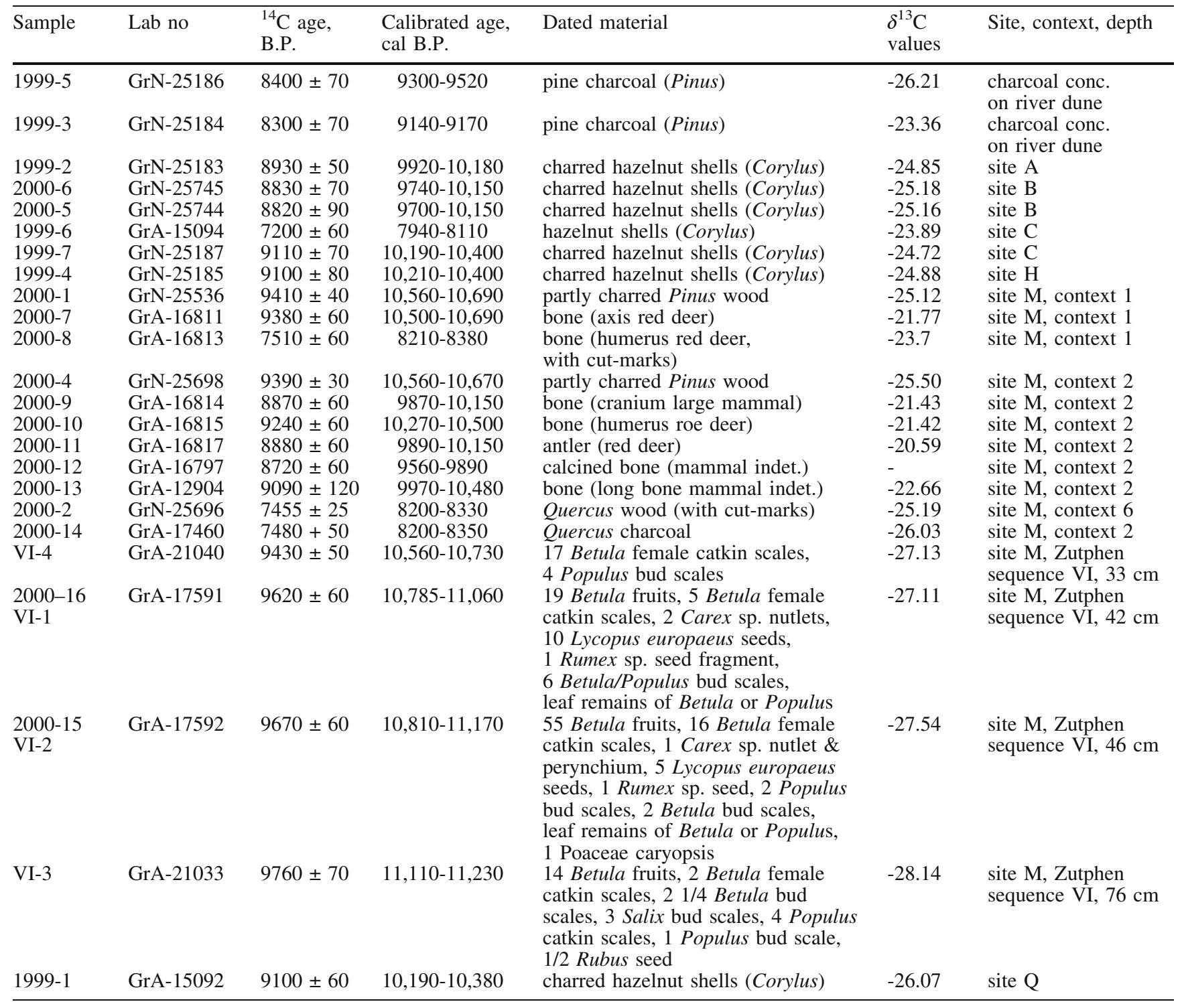

many levels microscopic epidermis fragments of charred grasses were observed (illustrated by Ralska-Jasiewiczowa and van Geel 1992). Furthermore, large numbers of small (1-5 mm) fragments of charcoal were found. These were probably herbaceous in origin as they were very easily broken. Peaks in macroscopic charcoal fragments corresponded with elevated levels of Poaceae pollen, occurrences of Phragmites caryopses and pollen records of Ranunculus acris (meadow buttercup), Solanum nigrum (black nightshade) and Plantago (plantain, inclusive P. major/media). Pollen grains of Poaceae larger than 40 $\mu \mathrm{m}$ (Cerealia size) probably originated from wild grasses such as Glyceria species.

The Zutphen-VI diagram can be correlated with the Borchert pollen record (van Geel et al. 1981) in the eastern Netherlands, ca. $60 \mathrm{~km}$ northeast from Zutphen. The Borchert record is well dated by radiocarbon samples (partly by ${ }^{14} \mathrm{C}$ wiggle-match dating; van der Plicht et al. 2004) and encompasses the period from the late Younger Dryas to Late Mediaeval period. Based simply on the palynological record, this part of the Zutphen-VI sequence would be correlated with the grass-dominated Rammelbeek Phase of the Preboreal (cf. Wijmstra and de Vin 1971; e.g., Behre 1966, 1978; van Geel et al. 1981). However, the Rammelbeek Phase was characterised by a regional expansion of grasslands. In the Zutphen-VI sequence, the macroremains indicate that the Poaceae maximum was caused by the extralocal presence of Phragmites. Also the radiocarbon date of $9760 \pm 70$ B.P. (Table 2) at $76 \mathrm{~cm}$ indicates that sediment accumula- 

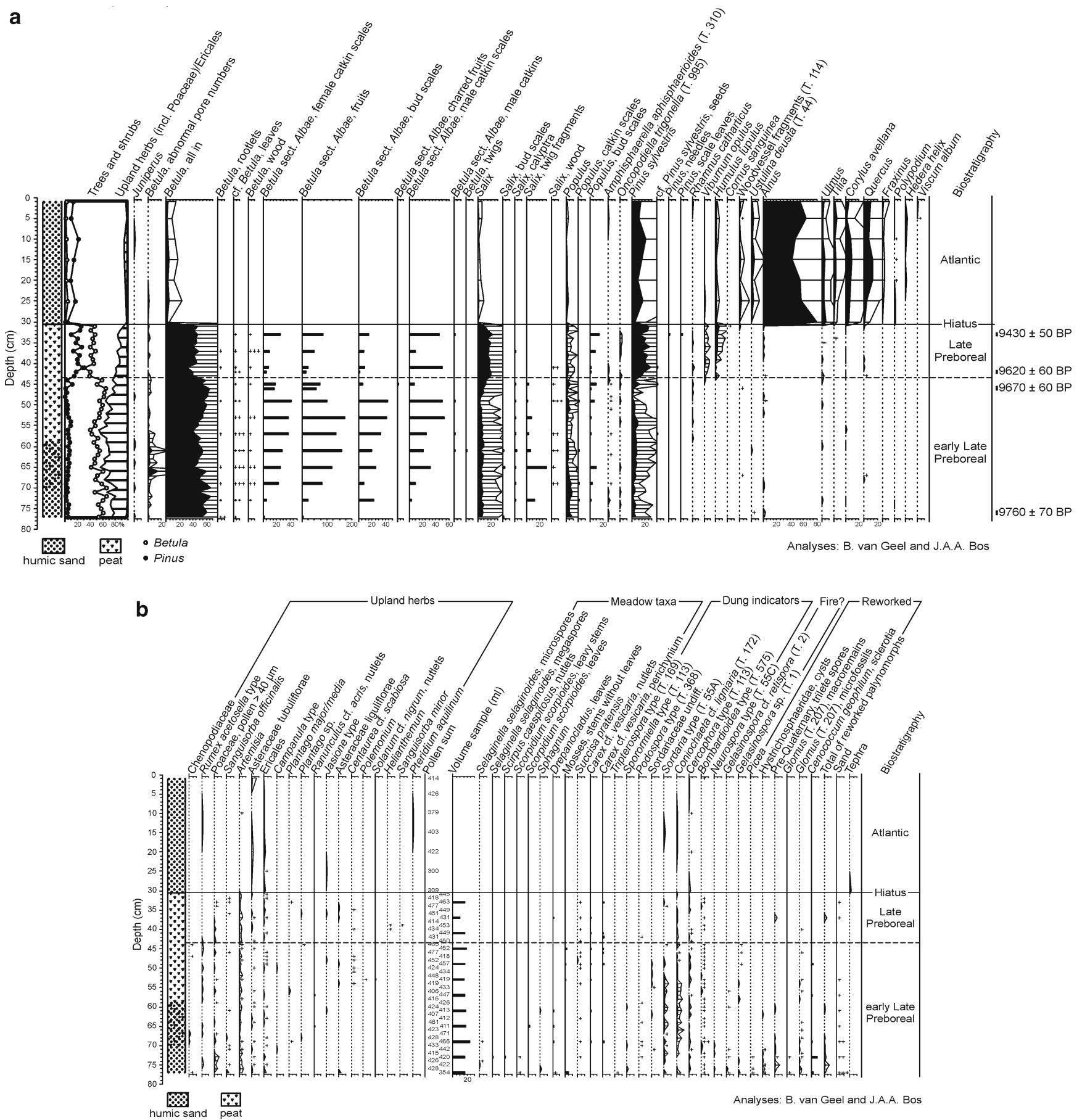

Fig. 4 Combined microfossil and macroremain diagram for the Zutphen-VI sequence. Microfossils (e.g., pollen, spores) are displayed by curves $(\%)$, macroremains by histograms giving total amounts or presence $(+)$ or abundance $(+=$ present,$++=$ abundant

tion started after the Rammelbeek Phase, at the beginning of the Late Preboreal. The start of the Late Preboreal was characterised by a more humid climate (van der Plicht et al. 2004). During this period groundwater levels may have been higher, which at the Zutphen-VI site probably induced the start of the accumulation of organic material. and $+++=$ very abundant). Exaggeration of pollen curves $5 \times$. In the different ecological groups (e.g., woodlands, shrubs, reed swamps etc.) also included are fungi that are indicative for this group or which have host species included in this specific ecological group

Between 49 and $41 \mathrm{~cm}$, a rise in the Pinus (pine) pollen values $>20 \%$ (rational limit of pine) is recorded. Pine pollen concentrations rise at $43 \mathrm{~cm}$ (Fig. 5). Betula remains the dominant tree pollen type and large numbers of macroremains are recorded. Pinus pollen is subdominant. Three tentatively identified fragments of pine seeds (small fragments of which the cell pattern resembled 

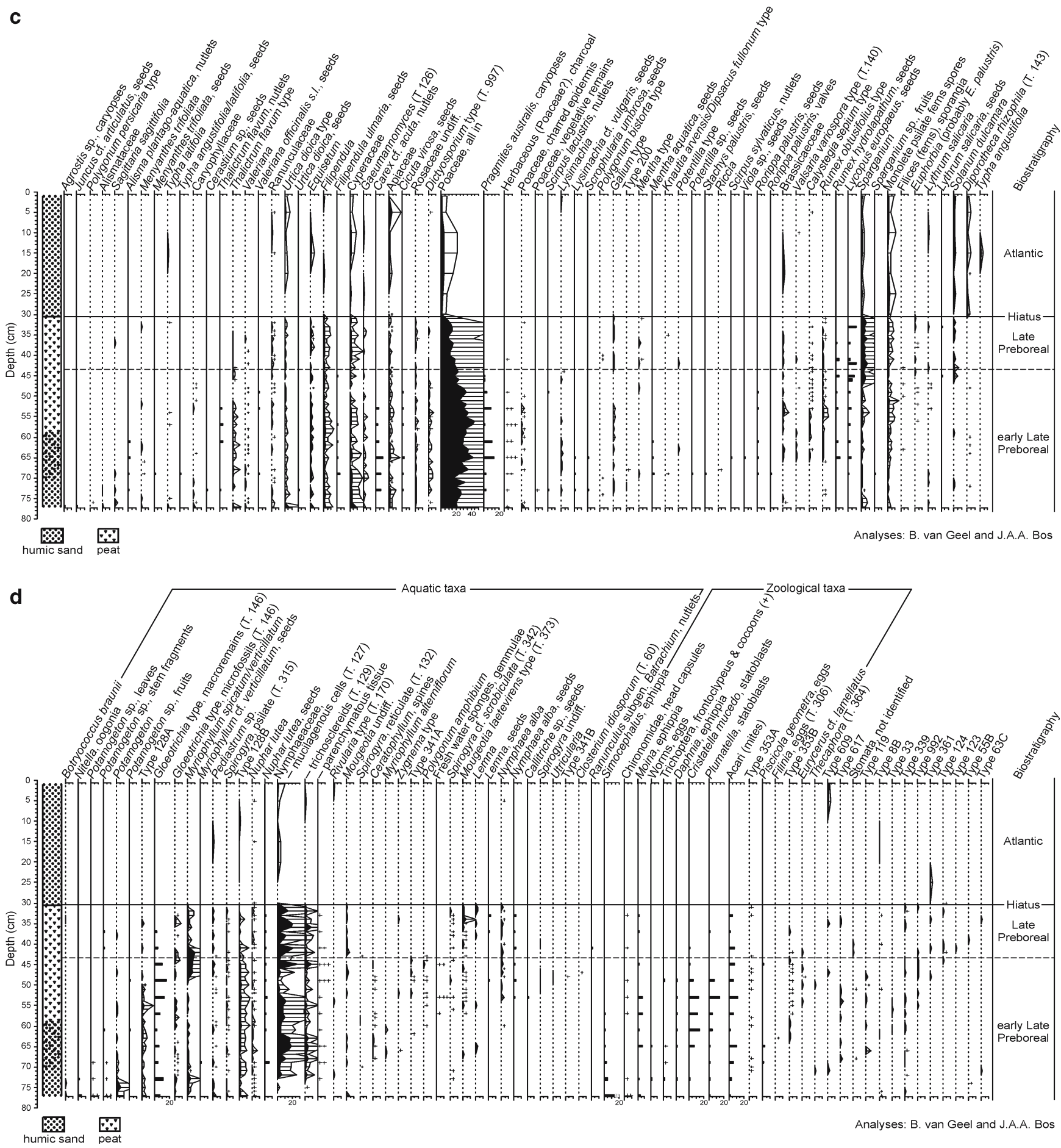

Fig. 4 (continued)

pine) were recorded. One fragment was found at $57 \mathrm{~cm}$, well below the increase in the pine pollen values with the other two immediately at the base of the pine pollen increase at 45 and $41 \mathrm{~cm}$. Scale leaves and remains of pine needles were recorded at $33 \mathrm{~cm}$ indicating that pine was present in the vicinity of the site.

Salix pollen is recorded in higher percentages (15$20 \%$ ) and concentrations (Figs. 4a and 5) than in the previous zone. However, hardly any macroremains of Salix were found. Populus pollen is recorded (4\%), accompanied by many well preserved bud scales. NAP values (especially Poaceae, Artemisia and Asteraceae) decrease to around $15 \%$.

Two radiocarbon dates at $46 \mathrm{~cm}$ and $42 \mathrm{~cm}$, encompassing the expansion of pine, yielded ages of $9670 \pm 60$ B.P. and $9620 \pm 60$ B.P. (Table 2) and indicate that pine 


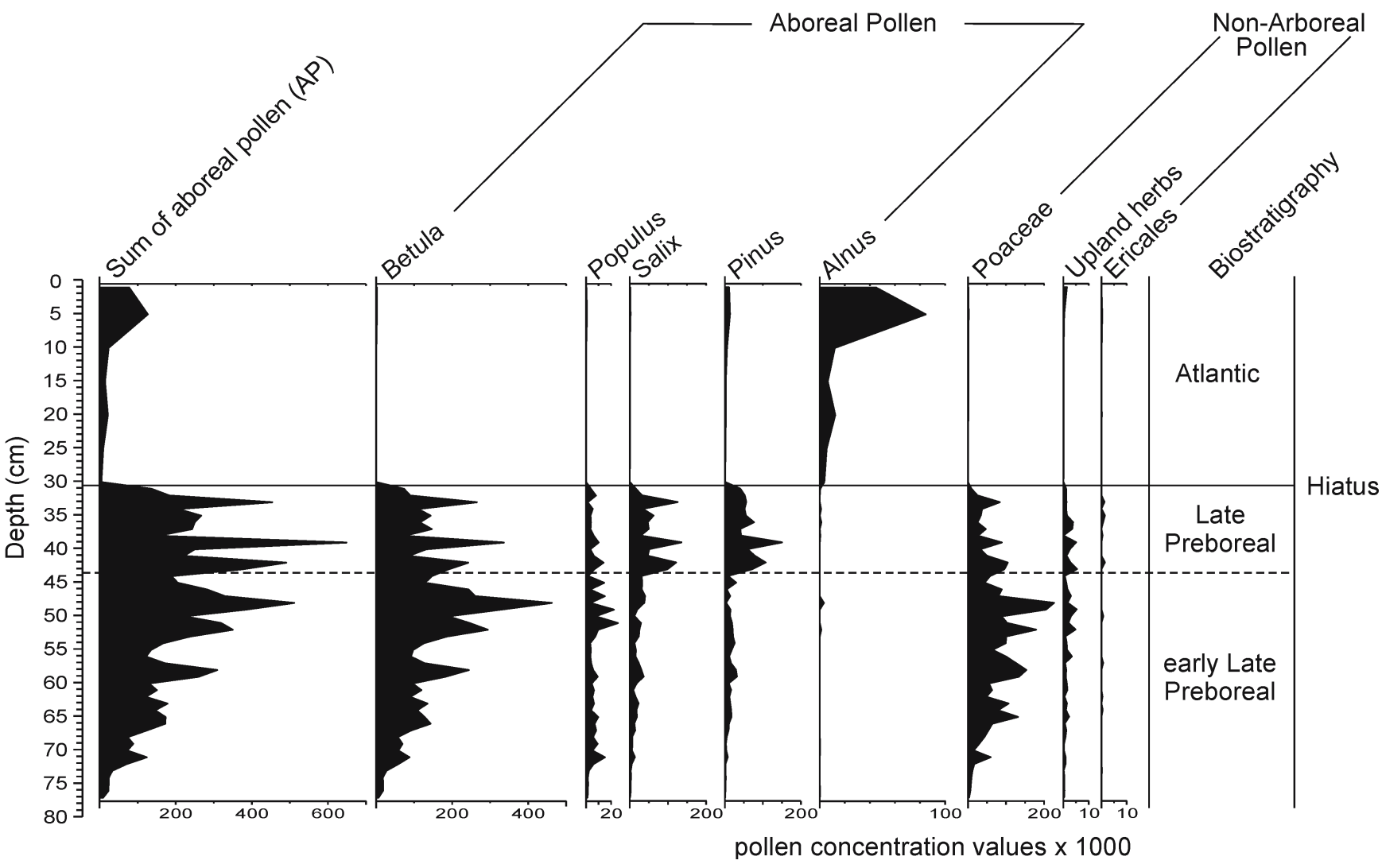

Fig. 5 Pollen concentration diagram for the Zutphen-VI sequence, showing a selection of taxa

migrated into the Zutphen area at around 9650 B.P. The timing of the immigration of pine in the Zutphen area is more or less similar to that in the Borchert area (van der Plicht et al. 2004). In the Borchert pollen diagram pine becomes dominant over birch very rapidly, while in the Zutphen-VI sequence birch remains dominant. This may suggest that the pine expansion is not fully recorded in the Zutphen-VI sequence. However, the large numbers of birch macroremains are probably the effect of the presence of the species in the vicinity of the sample site and therefore birch pollen may be overrepresented.

The arrival of Pinus at ca. 9650 B.P. occurs together with the arrival of Humulus lupulus (hop) and Viburnum (guelder-rose). The latter two taxa arrived later in the Borchert area, where Humulus arrived around 9450 B.P. and Viburnum much later, during the Boreal. Comparison of the ${ }^{14} \mathrm{C}$ wiggle-match dated Borchert record (van der Plicht et al. 2004) and the radiocarbon date of $9430 \pm 50$ B.P. at $33 \mathrm{~cm}$, suggests that the Preboreal sequence at Zutphen-VI ceased at the Late Preboreal/Boreal transition. The expansion of Corylus avellana (hazel) at the beginning of the Boreal was therefore not recorded at Zutphen. The lower part of the Zutphen-VI sequence, between $77-31 \mathrm{~cm}$, thus represents the complete Late Preboreal (zone 4c in Hoek 1997 and Hoek and Bohncke 2002).

A very abrupt shift in the diagram is visible between 31 and $30 \mathrm{~cm}$. Above $30 \mathrm{~cm}$ the spectra are dominated by
Alnus pollen and lower percentages of light demanding trees (Betula, Populus, and Pinus) are recorded. Furthermore, high values of Tilia (lime), Ulmus (elm), Quercus (oak) and Corylus are recorded. The dominance of Alnus pollen in the sandy samples above $30 \mathrm{~cm}$ suggests that the sediments are of Atlantic age (cf. van Geel et al. 1981). No indicators of human impact, such as Plantago lanceolata (ribwort plantain) or Cerealia were observed in the samples. This indicates that the deposits are younger than ca. 8000 B.P., but predate ca. 5300 B.P. A hiatus encompassing at least 1000 years is present between 31 and $30 \mathrm{~cm}$. Volcanic material (tephra) was recorded at $30 \mathrm{~cm}$, but the presence of this material at a hiatus-level precludes its use for detailed tephrochronology.

\section{Zoological results}

In Table 1 the zoological taxa that were recorded from the early Mesolithic contexts of site $\mathrm{M}$ are presented. From a total of 91 items one third could be identified to species level.

The only fishes identified were Esox lusius (pike) and Rutilus rutilus (roach). Pike prefers slow-running or stagnant, shallow waters with banks abundantly overgrown with vegetation. Roach is less selective and lives in all kinds of fresh waters (Nijssen and de Groot 1987). Their habitat is the bream zone of a river. This zone is 
characterised by slow-running and stagnant water, wide beds with a sandy or muddy bottom, and rich vegetation in the bank zone. The oxygen concentration is low and in summer the temperature often rises to more than $20^{\circ} \mathrm{C}$ (van Neer and Ervynck 1993). In addition to roach and pike, species such as Rutilus erythrophtalmus (rudd), Abramis brama (bream), Tinca tinca (tench), Cyprinus carpio (carp), Perca fluviatilis (perch), Siluris glanis (catfish) and Anguila anguila (eel) belong to this habitat. The presence of fish in these waters was also indicated by finds of Piscicola geometra eggs (Fig. 4d). Piscicola geometra is a leech of the Piscicolidae (Order Rhynchobdellae, Class Hirudinea), which lives in fresh water and is often found in combination with Myriophyllum, Ceratophyllum and Chara (Pals et al. 1980). As its name implies, it is a parasite on fish. Furthermore, a freshwater mollusc (Unio), mites (Acari), waterflees (Simocephalus, Daphnia and Moina), Chironomidae larvae (non-biting midges), Trichoptera larvae, statoblasts of Bryozoa (Cristatella mucedo, Plumatella repens), Filinia (rotifers) and flatworms (T. 353A, B) were recorded (Table 1, Fig. 4d). These finds are all consistent with the freshwater environment indicated by the fish and plant taxa referred to above.

The biotope of Sus scrofa (the wild boar) is very broad and covers both dry and wet areas: deciduous and mixed forests, shrubs, riverbank forest, reed swamps, marshes and older coniferous forests with dense undergrowth (Lange et al. 1994). According to Litjens (1992) they prefer half-open areas. Similarly the biotope of Cervus elaphus (the red deer) is rather broad. Red deer prefer open woods in river valleys and riverbank forest, but also live in other types of wood, marshes, heath and meadows. The availability of water and the accessibility of grass in winter are important; snow cover should be less than 30$40 \mathrm{~cm}$ (Lange et al. 1994). Capreolus capreolus (the roe deer) prefers parkland-wooded areas alternating with open fields. They prefer deciduous or mixed wood with some undergrowth. The woodland fringe in particular offers both food and cover. However, roe deer also can survive in open landscapes like reed swamps and marshes.

In Europe, Ursus arctos (the brown bear) today only inhabits rather inaccessible areas such as the mountains of the Alps, the Pyrenees, the Carpathians, Scandinavia and the Balkan Peninsula. Because of human activities such as hunting, agriculture and tourism its habitat has diminished and the species has been driven to marginal areas (Verstrael 1988). However, its original biotope was much broader. Brown bears live in extensive deciduous forests where a great variety of food is available. Their diet consists of berries, mushrooms, tender roots, green parts of plants, acorns, honey, fish, frogs, birds' eggs and various mammals from small rodents to deer. Its only natural enemy is man. The brown bear probably disappeared from the Netherlands entirely during the tenth century (Verhagen 1989).

Felis silvestris (the wild cat) lives in various kinds of woodland, open heathland and grassland, preferring stagnant water. In summer they visit all these areas, but in winter they do not leave the forest (Lange et al. 1994). Castor fiber (the beaver) prefers woodlands along all kinds of waters that have to be at least $50 \mathrm{~cm}$ deep (Lange et al. 1994). There is no preference for either running or stagnant water. Arvicola terrestris (the ground vole) lives on overgrown banks of brooks, rivers and lakes. It needs water at least $20 \mathrm{~cm}$ deep with banks no higher than a metre. Biotopes with a strongly varying water level are avoided (Lange et al. 1994).

\section{Discussion}

The Early Holocene palaeoenvironment

Modern analogues for the vegetation during the Early Holocene do not exist (Janssen 1970; Birks 1986). In order to come to a more spatial reconstruction of Early Holocene vegetation patterns, high-resolution studies along transects can be used for interpreting the Zutphen botanical sequence. Palaeobotanical investigations in and around a former Lateglacial lake near Milheeze, The Netherlands (Bos 1998; Bos et al. in press.) demonstrated that by the use of a transect of cores fine scale vegetation patterns could be reconstructed. During the Early Holocene the situation (e.g. a similar substrate) near Zutphen (Figs. 4 and 6) was probably not very different from that during the Allerød period near Milheeze. More or less similar vegetation patterns to those near Milheeze therefore may have occurred on the river dune and in the residual channel near Zutphen.

Based on changes in the forest composition the vegetation development during the Early Holocene can be subdivided into two phases. During the early Late Preboreal (Fig. 6a) the vegetation within the area can be characterised as follows: in the residual channel, initially aquatic vegetation was present with submerged taxa such as Potamogeton (pondweed) and Myriophyllum verticillatum (whorled water milfoil), Nitella (Charophytes), Gloeotrichia (Cyanobacteria) and various algae (Pediastrum, Botryococcus braunii, Spirogyra and Mougeotia species). Gloeotrichia probably played a role as a pioneer through its nitrogen-fixing ability. Humic sand was deposited. In these sandy deposits, river-transported pollen (Picea), pre-Quaternary spores, dinoflagellate cysts and Glomus chlamydospores (T. 207, van Geel et al. 1989) were recorded. This suggests that during this period redeposition of material occurred probably by flowing water. Also ascospores of the Neurospora type, indicative of local fires, may have been reworked. Furthermore, the water was slightly calcareous and mesotrophic conditions prevailed.

Fig. 6 Schematic cross-section through the river dune and residual channel during the Early Holocene near Zutphen. This figure is based on the overview and profile displayed in Figs. 2 and 3 respectively. The situation before (Fig. 6a) and after (Fig. 6b) the immigration of pine is shown 

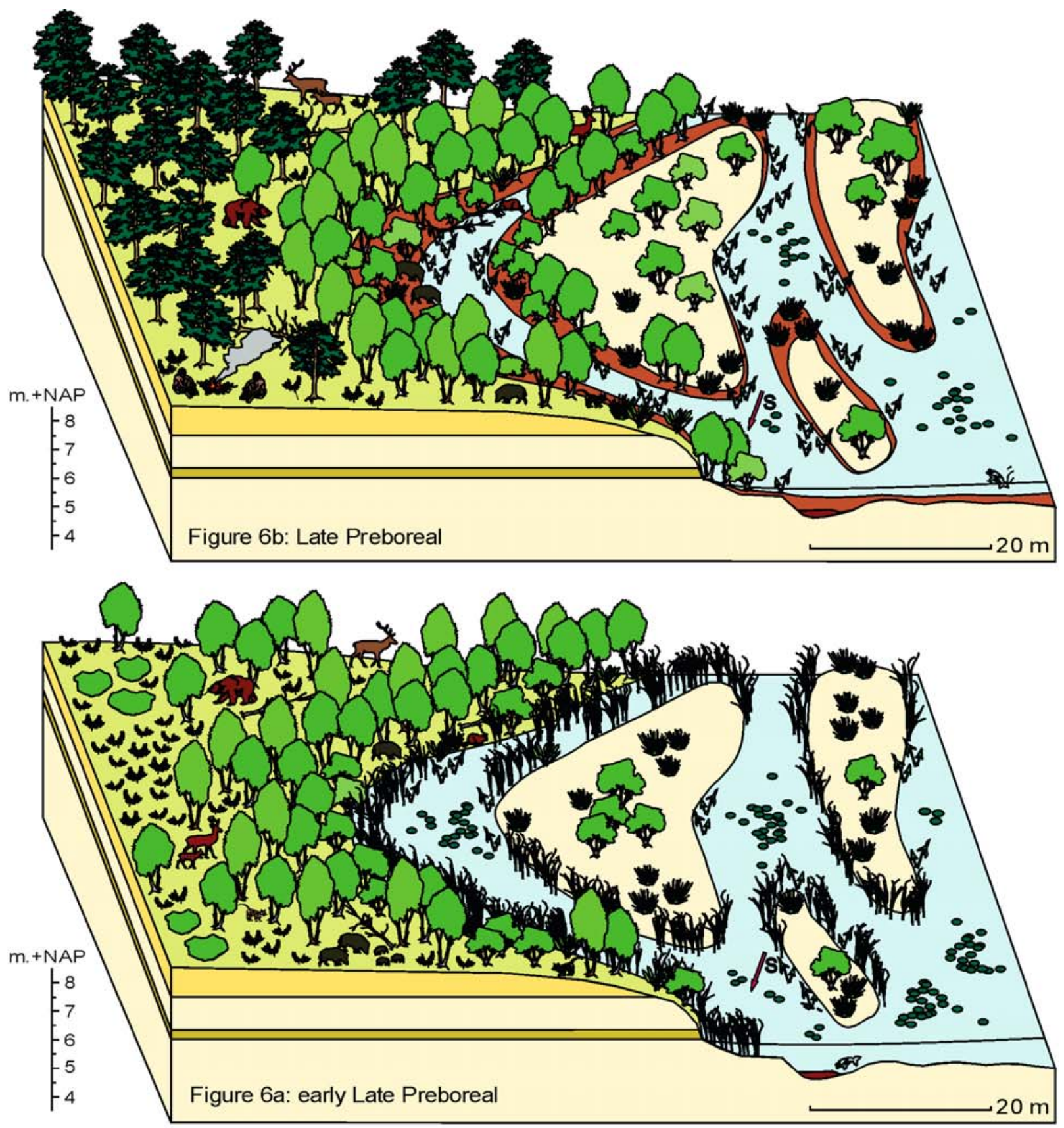

Lithology:

Dune sand - Late Weichselian probably Younger Dryas Coversand - Pleniglacial (Twente formation) Fluviatile \& fluvio-periglacial sand Early and Middle Weichselian

Humic sand - early Late Preboreal Peat or gyttja - Late Preboreal Soil cover

/s Assumed location of the sample spot

\section{Vegetation:}

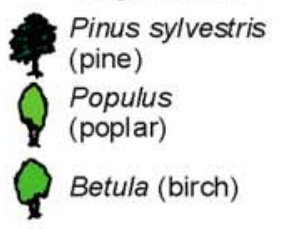

Salix (willow)

$\checkmark$ Junipenus (juniper)

a Viburnum, Cornus (guelder-rose,dogwood)
Fauna:

Cervus elaphus (red deer)

Capreolus capreolus (roe deer)

Ferns

Sedges

if Reed-swamp

Semi-aquatic

$\therefore$ Aquatics

Herbaceous egetation तर

An Sus scrofa (wild boar)

Unisus arctos (brown bear)

Felis silvestris (wild cat)

Q Castor fiber (beaver)

Design: J.A.A. Bos 
Plate 1 Ascospores of the Bombardioidea type, showing subapical pores, often arranged in a pseudo-circle. The basal ends showing the remains of an originally cellular, or gelatinous (not fossilised), eccentrically placed appendage, with a small central pore $(4,5)$
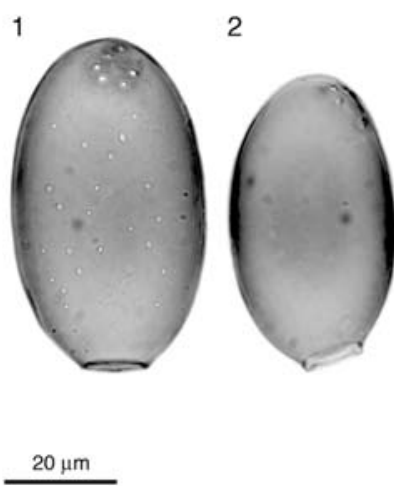

Later, the water became stagnant and sandy peat was deposited. Floating aquatics such as Nuphar lutea (yellow water-lily) and Polygonum amphibium (amphibious bistort), and more submerged taxa such as Myriophyllum alterniflorum (water milfoil) and Ceratophyllum (hornwort) appeared. Large amounts of parenchymatous tissue and high values of mucilaginous cells and trichosclereids also indicate the local presence of Nymphaeaceae. Finally, Nymphaea alba (water-lily), Lemna (duckweed), Callitriche (starwort), Utricularia (bladderwort) and algae such as Spirogyra cf. scrobiculata, Closterium idiosporum and Mougeotia laetevirens type appeared. The occurrence of these taxa together with Type 128B (probably an algal species) and ascospores of Valsaria variospora type (T. 140) further up in the sequence suggests that during this period the water level in the residual channel slowly decreased, while the nutrient status shifted from mesotrophic to eutrophic (cf. Runhaar et al. 1987; van Geel and Grenfell 1996; van Geel et al. 1989, 2003). Ephippia of waterfleas (Daphnia and Moina) recorded in this interval also indicate such conditions.

With the appearance of floating aquatics, reed swamp vegetation also settled around the channel edge. Here, Phragmites australis (reed), Alisma plantago-aquatica (water-plantain), Carex (sedge), Cicuta virosa (crowbane), Equisetum (horse-tail), Filipendula ulmaria (meadowsweet), Lycopus europaeus (gypsywort), Lysimachia vulgaris (yellow loosestrife), Mentha aquatica (water mint), Menyanthes trifoliata (bogbean), Rumex hydrolapathum (water dock), Thalictrum flavum (meadow-rue), Typha latifolia (bulrush), Valeriana officinalis s.l. (valerian) and many others (Fig. 4c) were present. A number of these taxa can also occur on damp soils in open woodland, shrub or tall-herb vegetation. The presence of Solanum dulcamara (bittersweet) was also indicated by records of ascospores of its parasite Diporotheca rhizophila (T. 143). Higher values of Dictyosporium type conidia (T. 997) are probably related to the establishment of this reed swamp vegetation along the channel edge, as this fungus grows on decaying wood and on stems of herbaceous plants (O'Connell et al. 2001). Furthermore, records of Eurycercus cf. lamellatus confirm that rooted aquatic vegetation was present.
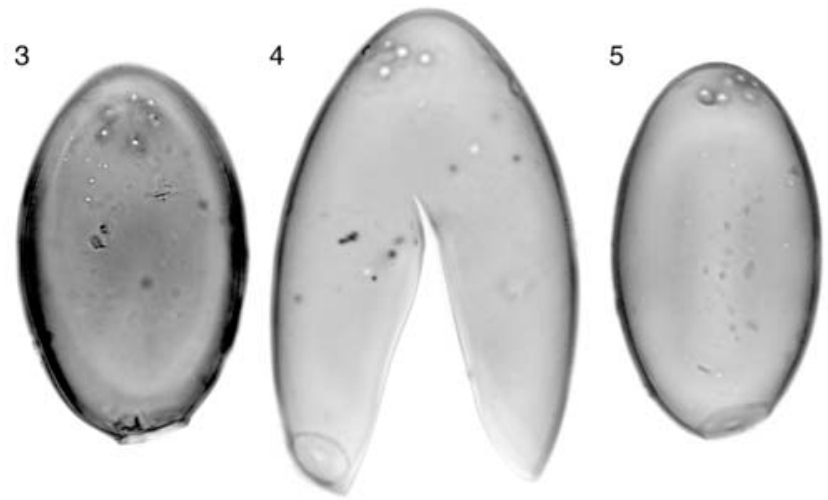

The large quantity of Salix macroremains indicates that shrub willow was present amongst the reed swamp vegetation. The high birch pollen percentages and large numbers of birch macroremains in this interval suggest that behind the shrub willow, woodland with both Betula pendula and $B$. pubescens was present. However $B$. pendula may also have been growing on the dryer soils. Populus tremula was probably intermingled with the birches on the slightly higher ground, with the parasitic fungus Amphisphaerella amphisphaerioides (T. 310, van Geel 2001) infecting the poplar trees. Scirpus sylvaticus (wood club-rush), Scrophularia umbrosa (green figwort), Urtica dioica (nettle) and ferns may have grown in these woodlands. Records of Oncopodiella trigonella conidia (T. 995, O'Connell et al. 2001) also confirm the nearby presence of stands of trees. Temporarily lower values of Populus pollen and macroremains are recorded between 65 and $49 \mathrm{~cm}$, while Phragmites grew locally. The establishment of a reed swamp along the shore probably partly prevented the relatively large and heavy bud scales of Populus from reaching the open water around the sample site. However, the light, wind-transported fruits, bud scales and catkin scales of Betula could still reach the sample site.

On the river dunes, herbaceous vegetation with Artemisia (mugwort), Centaurea scabiosa (greater knapweed), Campanula (bellflower), Chenopodiaceae (goosefoot), Rumex acetosella (sheep's sorrel), Sanguisorba officinalis (great burnet), Plantago, and scattered Juniperus (juniper) and Rhamnus scrub was probably present. Wet meadows were present with Juncus articulatus, Succisa pratensis (devilsbit scabious), Selaginella selaginoides, Sphagnum and Scorpidium scorpioides, with Juncus, Salix and Cyperaceae (sedges) on the sandbanks.

During the Late Preboreal (Fig. 6b), Pinus sylvestris, Viburnum, Cornus sanguinea (dogwood) and Humulus lupulus migrated into the Zutphen area. Pine established itself on the poorer, sandy substrates, such as the river dunes, where it replaced juniper and may have grown alongside Betula pendula. Some meadows and herbaceous vegetation persisted with Artemisia, Centaurea scabiosa, Helianthemum (rockrose), Sanguisorba minor 
(salad burnet) and Jasione (sheepsbit scabious) on the dryer, poorer soils of the river dunes.

Between the river dunes and along residual channels, woodlands remained present with Betula pendula, $B$. pubescens, Populus and shrubs of Salix, Viburnum and Cornus sanguinea, together with Humulus as a climber on the shrubs and trees. Woodlands were in general more closed than during the preceding period. High Salix pollen values were recorded but almost no macroremains were found. Willow pollen is not normally transported far from its source. The relatively high pollen percentages in the upper part of the diagram therefore suggest production by willow species growing along the lake-edge and sandbanks, not far from the sampling point.

On the shores near the sample site, shrub willow and birch woodlands had replaced Phragmites. Here, also Equisetum, Lycopus europaeus, Lythrum salicaria, Rumex hydrolapathum and Sparganium were present. During this period, infilling of the residual channel proceeded and the shrub and woodland zone with Salix, Betula and Populus had moved towards the sample site. Slightly higher values of the fungus Oncopodiella trigonella conidia recorded in the deposits also indicate that stands of trees were growing in the vicinity.

In summary, the flora indicates a mosaic of many different vegetation types, ranging from that of slow flowing or stagnant open water, marshes, reed swamps and shrubs to woodlands including riverbank, deciduous, and open coniferous forests. The mammal species, including wild boar, red and roe deer, brown bear, wild cat and ground vole taken as a group indicate a half-open landscape where woodland alternated with reed swamps, marshes and meadows. Slow flowing or stagnant shallow water is indicated by records of numerous plant taxa, fish, a mollusc, mites, waterfleas, larvae of non-biting midges and Trichoptera, Bryozoa, rotifers and flatworms. The presence of beaver suggests that at some places the water depth was at least $50 \mathrm{~cm}$. Most aquatic plant taxa (e.g., Myriophyllum, Nymphaea alba, Ceratophyllum) also need a water depth of more than $25 \mathrm{~cm}$. The flora and fauna recorded at Zutphen are thus consistent with each other. Although not found in the deposits, mammals such as aurochs (Bos primigenius), elk (Alces alces) and otter (Lutra lutra) could have been expected in these environments (e.g. Gramsch and Kloss 1989; Street 1991).

\section{Effects of human interference?}

During the Early Holocene favoured places for Mesolithic settlements in NW and central Europe were the higher ridges, e.g., river dunes and coversand ridges, with close access to water, such as the margins of lakes and residual channels (e.g. Schmitz 1961; Kloss 1987b; Street 1991; Gronenborn 1992; Hahn et al. 1993; Kind 1997; Heinen 1999; Urz 2000; Bos and Urz 2003). Thus, at the Zutphen-Ooijerhoek site early Mesolithic people built their settlements on a river dune along a residual channel (Groenewoudt et al. 2001). In their study of the
Mesolithic site at Star Carr, Mellars and Dark (1998) stressed the exceptional economic productivity of lake edge environments. In such ecotone situations, resources are available from entirely different ecosystems, i.e. not only from those of the lake itself, but also from the rich, diverse and biologically productive habitats of the eutrophic lake margin and the adjacent dry land forest zones. Herbivores are attracted by the high productivity of plant species and use lakeshores as foraging and watering places, making such lake margin areas reliable and predictable hunting locations.

At the Zutphen-Ooijerhoek site, the presence of Mesolithic people was not only indicated by finds of artefacts, but also evidenced by the record of a human milk tooth (context 3, Fig. 2; Table 1) from a 9-10 year old child. The Zutphen-VI diagram reflects the fluvial landscape during the first part of the early Mesolithic occupation. Radiocarbon dates in the upper part of the Late Preboreal sequence gave a calibrated age between ca. 11,170 and 10,560 cal B.P. (9650 to 9430 B.P., Table 2). From site $M$, the oldest radiocarbon date was obtained from a partly charred piece of pinewood and gave an age of $9410 \pm 40$ B.P. (10,690-10,560 cal B.P., Table 2). The calibrated age of this sample overlaps with the range of the upper dates in the Zutphen-VI diagram. The Late Preboreal part of the diagram thus just reflects the first phase of early Mesolithic occupation (between ca. 9200 and 9400 B.P) that was evidenced by archaeological finds. In this part of the diagram unambiguous anthropogenic indicators have not been found. However, even if the distance to where man was active in the vegetation is very small it still may be impossible to detect human induced changes (Behling and Street 1999). Pollen records of Urtica and Plantago may point to trampling, disturbance and/or eutrophication as a result of the presence of either large herbivores or man along the shores of the residual channel. However, Urtica also may have grown in its natural habitat along the eutrophic lakeshore. Records of ascospores of the coprophilous Cercophora type, Bombardioidea type (Plate 1) and Sporormiella type (Davis 1987; van Geel et al. 2003) may point to the presence of herbivore dung (Lundqvist 1972; van Geel 1978; van Geel et al. 2003) and indicate that trampling zones along the lake edge may have been present. Spores of Coniochaeta cf. ligniaria may also have had dung as a substrate; however the species also grows on wood (Munk 1957; van Geel et al. 1983). The presence of large herbivores in the immediate environment of the ZutphenOoijerhoek site was also indicated by records of large herbivore bones (Tables 1 and 2).

However, the evidence recorded during the period before the expansion of pine, reflected by the early Late Preboreal part of the Zutphen-VI diagram contrasts with this. This part of the diagram, dated between ca. 11,230 and 10,790 cal B.P. (9760 to 9650 B.P., Table 2), shows some kind of interference within the landscape, possibly indicating human impact. However, there is no archaeological record of the presence of man in the ZutphenOoijerhoek area from this period. Nevertheless, it is 
possible that records of Mesolithic settlements were missed during the excavations because either the settlements reflecting this early period were located outside the limits of the excavated area, or the activities associated with the presence of Mesolithic people in the area did not leave archaeological traces.

During the early Late Preboreal, grasses show relatively high pollen percentages, while caryopses of Phragmites australis, charred epidermis fragments of grasses and peaks of charcoal fragments occur regularly. This indicates that natural or man-made fires occurred during this period. The local presence of Phragmites close to the site, in combination with records of charred grass epidermis material and macroscopic charcoal fragments, suggests that these could have been the result of in situ burning of the reed swamp (compare Mellars and Dark 1998). Occurrences of Rumex acetosella, Solanum nigrum, Plantago, Rorippa palustris (yellow cress) and Stachys palustris at the same level as the charcoal peaks also suggest disturbance and exposure of new substrates for pioneer plants (Runhaar et al. 1987) along the channel edges. Moreover finds of Ranunculus acris nutlets correspond with the macroscopic charcoal peaks. $R$. acris can grow in places where vegetation has been recently cut down (van der Meijden et al. 1983). The presence of Urtica may have been caused by eutrophication as a result of burning practices. The purpose of deliberate burning could have been to create openings in the vegetation, which induced the growth of herbs, forbs and shrubs in order to attract herbivores. Fire also could have been used as a direct hunting technique in order to drive game together. For the Star Carr site, Mellars and Dark (1998) suggested that active burning of the reed swamp occurred to keep the occupation area largely free of reeds and other plant growth, and to maintain visibility and easy access to the lake. The Zutphen-Ooijerhoek botanical data may suggest the same thing.

During the early Late Preboreal (ca. 11,230-10,790 cal B.P.), (large) herbivores were also present in the immediate environment, as ascospores of the coprophilous Cercophora type, Sordaria type, Podospora type, Bombardioidea type, Sporormiella type and Coniochaeta cf. ligniaria (the latter grows on wood as well, e.g. Munk 1957; van Geel et al. 1983) indicate the presence of dung. Increased values of Poaceae pollen and finds of Phragmites australis caryopses and charcoal between 73$52 \mathrm{~cm}$, also correspond to peaks in the amount of coprophilous fungi. This suggests that during this interval trampling zones along the lake edge were more abundant. Higher numbers of ascospores of Cercophora type, Sporormiella type, Coniochaeta spp., and Chaetomium during post-disturbance-transitional phases were also recorded from the North Gill 5 late Mesolithic site (Innes and Blackford 2003). In their study, fungal spore analysis supported the ecological interpretations of the pollen and charcoal data and provided more direct evidence of animal concentrations in Mesolithic-age post fire areas.
Means of subsistence

At the Zutphen-Ooijerhoek site hunting probably formed an important part of the subsistence activities of the early Mesolithic people. This was evidenced by finds of bones of large herbivores, such as roe deer and red deer. Also bones of wild boar, brown bear, wild cat, beaver and ground vole were found. Some of the antler bones of red deer were made into tools or could have held stone artefacts made for hunting (Groenewoudt et al. 2001). Also cut-marks appeared on various pieces of bones of wild boar and red deer, and other modifications, such as gnawing and burning, were recorded on the animal remains (further details in Groenewoudt et al. 2001). In addition to records of bones and artefacts, botanical evidence of the presence of mammals during the Late Preboreal is provided by finds of ascospores of coprophilous fungi.

There is no archaeological evidence for fishing activities at the Zutphen-Ooijerhoek site. However, roach and pike were present in the residual channel, as fish bones of these species were recorded in the sediments. The presence of fish in the water was also indicated by the presence of the parasitic leech Piscicola geometra.

Botanical studies of occupation layers of Mesolithic sites, such as from Tybrind Vig, Denmark (Kubiak-Martens 1999), provide information on the type and parts of plants that were gathered during the Mesolithic, i.e. berries, fruits, seeds and root vegetables. The microfossil and macroremain diagram (Fig. 4) shows that also at the Zutphen-Ooijerhoek site a wide range of edible plants must have been present (Renfrew 1973; Körber-Grohne 1987; Brøndegaard 1987; Oberdorfer 1994; Perry 1997, 1999; Kubiak-Martens 1999, 2002). For example, wild berries of Rosa and Viburnum opulus and drupes of Cornus sanguinea may have been eaten, while plants such as Rumex acetosa, Urtica dioica and Chenopodiaceae could have been used as green vegetables. The seeds of the latter are also edible. Also the tubers of Sagittaria sagittifolia and rhizomes of Scirpus lacustris, Phragmites australis, Nuphar lutea, Nymphaea alba, Equisetum, Humulus, and Typha may have been used as root vegetables. Filipendula ulmaria, Valeriana officinalis, Menyanthes trifoliata and Solanum dulcamara may have been used as medicinal plants (Oberdorfer 1994).

\section{Comparison with other sites}

Microfossil and macroremain records from other sites dating to approximately the same age, e.g., BedburgKönigshoven (Street 1989, 1991; Behling and Street 1999) and Weimar-Niederweimar (Urz 2000; Bos and Urz 2003), both in Germany, reflect a similar fluvial landscape to that near Zutphen. The locations of the early Mesolithic settlements on the river dunes or rims of terraces along residual channels at Bedburg-Königshoven, Weimar-Niederweimar and near Zutphen are very similar, and it is not surprising that in these studies taxa are found 
Table 3 Other radiocarbon dates from the valley of the Ooijerhoekse Laak. Calibrated using the CaLIB 4.4 program (Stuiver and Reimer 1993)

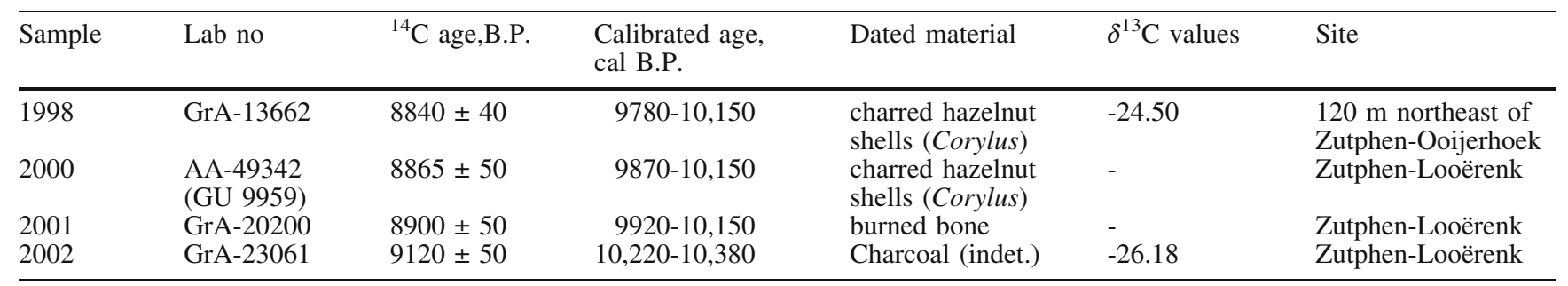

that indicate analogous local environmental conditions. Furthermore the fauna near Zutphen (Groenewoudt et al. 2001) with roe deer, red deer, wild boar, brown bear, beaver and wild cat, is comparable to the faunas of other Mesolithic sites, e.g., Star Carr (Clark 1954; RowleyConwy 1998), Bedburg-Königshoven (Street 1989, 1991), Friesack (Gramsch and Kloss 1989), and WeimarNiederweimar (Urz 2000).

The disappearance of Mesolithic habitation after 8700 B.P.

From the river dune and residual channel there are a number of dates from archaeological samples that concentrate around 8900-8700 B.P. (Table 2). Also other Mesolithic sites in the Ooijerhoeksche Laak river valley, such as from the Zutphen-Looërenk site, ca. $1.5 \mathrm{~km}$ eastwards from Zutphen-Ooijerhoek, reveal ages between 9100 and 8800 B.P. (Table 3). However, Mesolithic sites that date from after ca. 8700 B.P. were not recorded. This suggests that around 8700 B.P. Mesolithic habitation in the Zutphen area ceased. Three possible causes for this phenomenon will be discussed below.

Firstly, woodlands may have become too dense to survive, e.g., make settlements, to hunt and to gather. As a result of the ameliorated climate and immigration of species during the Early Holocene, the vegetation in NW Europe changed considerably. During the Preboreal, in the fluvial landscape near Zutphen initially willow and reed swamp vegetation was found along the shores of the residual channels. Nearer the river dunes, birch-poplar woodlands were present, with open vegetation containing Artemisia, Rumex, Plantago and juniper shrubs on the dunes themselves. Towards the end of the Preboreal, the vegetation became denser. Birch-poplar woodlands replaced the reed swamps on the shores, where also willow remained and hop was a climber in the shrubs and trees. On the river dunes, pine woodlands became established. During the Boreal, studies from analogous situations such as near Zutphen (e.g., Weimar-Niederweimar; Bos and Urz 2003), demonstrate that the vegetation became more diverse and increasingly dense as Corylus, Quercus (oak) and Ulmus (elm) expanded. Shrub hazel became established on the higher terraces where pine woodlands were also present, while on the river floodplains and along the (residual) channels, shrubbery and woodland could be found containing willow, birch, oak, elm and hop. During the Late Boreal, woodlands may have become increasingly more closed, especially on the higher river terraces and dunes. The dense forests would have led to a considerable decrease in grazing opportunities for large herbivores, which had formed man's major food source. For Mesolithic people this may have become a reason to abandon the area.

For the coversand area of the northern Netherlands, Waterbolk (1999) studied the chronological and geographical distribution of Early Holocene ${ }^{14} \mathrm{C}$ dated fireplaces. He suggests that man left the upland areas and moved to the lower courses of rivers and their estuaries during the period when forests became too dense. For these northern coversand areas this occurred at the beginning of the Atlantic period. Waterbolk also suggested, based on the observed occupation pattern, that the hypothesis of Vera (2000), that the natural, pre-Neolithic vegetation of the uplands was an open parkland landscape with an important role for large herbivores, has to be rejected. Based on our observations at the Zutphen-Ooijerhoek site, we have come to a similar conclusion. However, increasingly dense vegetation during the Boreal period is probably not the only reason that Mesolithic habitation ceased in the Zutphen area. There are indications that Mesolithic people were able to keep at least part of the vegetation open through management by fire (Zvelebil 1994; Mellars 1976; Smith et al. 1989; Moore 2000). For example, at a number of Mesolithic sites in western Europe there is evidence of deliberate burning of reed swamp vegetation (Mellars and Dark 1998) or woodlands (Jacobi et al. 1976; Welinder 1989; Ralska-Jasiewiczowa and van Geel 1992; Simmons 1993; Caseldine and Hatton 1993; Bos and Urz 2003; Innes and Blackford 2003). Therefore, there may have been other reasons for Mesolithic people to abandon the Zutphen area.

Secondly, the absence of Mesolithic settlements from 8700 B.P. on does not prove the absence of people. Settlements may have been moved to nearby areas, but people continued to exploit the river valley in a more extensive way, due to the increasingly dense woodlands. Records of a hewn oak and a bone of red deer with cutmarks dated at $7455 \pm 25$ B.P. and $7510 \pm 10$ B.P. respectively point to the presence of people in the Zutphen area during the middle Mesolithic. This may support the hypothesis of continued presence of Mesolithic people in this area. However, there still remains a gap of around 
1200 calendar years between the early and middle Mesolithic radiocarbon dates.

A third reason for the absence of Mesolithic settlements in the Zutphen area after 8700 B.P. may have been that open water disappeared as consequence of the hydroseral succession process in the residual channels. During the Preboreal and Boreal, the present-day river Ooijerhoeksche Laak may have flown in a valley more towards the IJssel river valley, relatively far away from the Mesolithic sites at Zutphen-Ooijerhoek. The presence of open water was probably one of the most important subsistence requirements for Mesolithic people, as well as animals, to be present in an area. Abandoned river channels, in which accumulation of organic deposits started during the Preboreal, are often remnants of braided rivers systems that were active during the Younger Dryas period. A braided river is characterised by many relatively shallow channels. When these shallow channels are abandoned at the same time, for instance, when a river changes its pattern from braided to meandering, accumulation of organic deposits can start in all residual channels. Such an abrupt change from a braided to a meandering pattern occurred in the large Dutch river systems of the Rhine and the Meuse at the beginning of the Holocene (Kasse 1995; Kasse et al. 1995; Berendsen et al. 1995). The many different channels that showed up in the lowest part of the meander infill at the ZutphenOoijerhoek site, and which were contemporaneous with the earlier part of the Mesolithic habitation, were probably the remnants of such a braided river system. In the Zutphen area, complete infilling of open water in the residual channels may have occurred synchronously around 8700 B.P. over a larger area within the same river valley. Synchronous infilling of a large number of residual channels from the same age is also known from the Rhine-Meuse river area in the central part of The Netherlands (H. Berendsen, Utrecht, pers. comm. 2003). When around 8700 B.P. infilling of the residual channels was completed and no open water was left, the Mesolithic people probably moved their settlements to areas where open water was still available.

\section{Conclusions}

The vegetation near Zutphen was reconstructed in detail for the Late Preboreal period. For the period between ca. 9800-9600 B.P., the botanical sequence showed that there are indications of either natural or man-made burning of the reed swamp vegetation along the residual channel; also trampling zones along the lake edge were more abundant. However, there were no nearby archaeological sites recovered, but these could easily have been missed for several reasons. The first phase of early Mesolithic habitation between ca. 9400 and 9200 B.P. was partly covered by the botanical sequence. As a result of a hiatus in the deposits, the second phase of early Mesolithic habitation (between ca. 8900 to 8700 B.P.) could not be recorded.
The river dunes along a residual channel near Zutphen were a favourable place for early Mesolithic huntersgatherers to live. The sites were high and dry and generally out of the reach of the floods, with an easy access to open water. Apart from hunting (and fishing) as a subsistence activity (e.g., fish, birds, wild boar, red deer, roe deer, brown bear, wild cat and beaver), the rich botanical assemblages show that the natural environment of the early Mesolithic people provided sufficient food for gathering (e.g. berries, seeds, fruits and green and root vegetables). Mesolithic people may have left the area when, as a result of infilling of the residual channels, open water was no longer available.

Description, illustration and indicator value of the Bombardioidea type (T. 575, Plate 1)

The ascospores are dark-brown, ellipsoidal, (51-)58-69($79) \times 33-41 \mu \mathrm{m}$, with $5-6$ subapical pores in a pseudocircle. The other end shows the remains of an originally cellular, or gelatinous (not fossilised), eccentrically placed appendage. The base of this appendage is about 12 $\mu \mathrm{m}$ in diameter, with a small central pore.

The ascospores of the Bombardioidea type occur regularly (always in low frequencies) in Lateglacial and Early Holocene deposits from the Netherlands, but until now it has not been observed in younger deposits. The spores differ from all known species in the genus Bombardioidea by their relatively large dimensions. All Bombardioidea species are dung inhabiting. The species B. anartia occurs on dung of European Elk (Alces alces) (Krug and Scott 1994). The fossil spores might be an example of an extinct fungal species, because the dungproducing animal (Alces alces?) became extinct in the Netherlands.

Acknowledgements The investigations were (in part) supported by the Research Council for Earth and Life Science (ALW) with financial aid from The Netherlands Organisation for Scientific Research (NWO, project number 8811.32.002). Jan van Arkel and Annemarie Philip are thanked for technical support. Jos Deeben, Otto Brinkkemper and Henk Berendsen are thanked for valuable discussions. Furthermore, we would like to thank two anonymous referees for useful comments on an earlier version of the manuscript

\section{References}

Behling H, Street M (1999) Palaeoecological studies at the Mesolithic site Bedburg-Köninghoven near Cologne, Germany. Veg Hist Archaeobot 8:273-285

Behre K-E (1966) Untersuchungen zur spätglazialen und frühpostglazialen Vegetationsgeschichte Ostfrieslands. Eiszeitalter und Gegenwart 17:69-84

Behre K-E (1978) Die Klimaschwankungen im europaischen Präboreal. Petermanns Geographische Mitteilungen 2:97-102

Berendsen HJA, Hoek WZ, Schorn EA (1995) Late Weichselian and Holocene river channel changes of the rivers Rhine and Meuse in The Netherlands (Land van Maas en Waal). Paläoklimaforschung/Palaeoclimate Research 14:151-171 
Birks HJB (1986) Late-Quaternary biotic changes in terrestrial and lacustrine environments, with particular reference to north-west Europe. In: Berglund BE (ed) Handbook of Holocene Palaeoecology and Palaeohydrology. Wiley, Chichester, pp. 3-65

Bos JAA (1998) Aspects of the Lateglacial-Early Holocene vegetation development in Western Europe. LPP Contributions series, 10

Bos JAA, Janssen CR (1996) Local impact of Palaeolithic Man on the environment during the end of the Last Glacial in The Netherlands. J Archaeolg Sci 23:731-739

Bos JAA, Urz R (2003) Lateglacial and Early Holocene environment in the middle Lahn river valley (Hessen, central-west Germany) and the local impact of Early Mesolithic man-pollen and macrofossil evidence. Veg Hist Archaeobot 12:19-36

Bos JAA, Bohncke SJP, Janssen CR (in press) Lake level fluctuations and small-scale vegetation patterns during the Lateglacial near Milheeze, southern Netherlands. Journal of Paleolimnology

røndegaard VJ (1987) Folk og Flora 1. Dansk etnobotanik, København

Caseldine C, Hatton J (1993) The development of high moorland on Dartmoor: fire and the influence of Mesolithic activity on vegetation change. In: Chambers FM (ed) Climate change and human impact on the landscape. Chapman \& Hall, London, pp. $119-131$

Clark JGD (1954) Excavations at Star Carr. An early Mesolithic site at Seamer near Scarborough, Yorkshire. Cambridge University Press, Cambridge

Davis OK (1987) Spores of the dung fungus Sporormiella: increased abundance in historic sediments and before Pleistocene megafaunal extinction. Quatern Res 28:90-294

Day SP (1993) Preliminary results of high-resolution palaeoecological analyses at Star Carr, Yorkshire. Cambridge Archaeological Journal 3:129-133

Day SP, Mellars PA (1994) 'Absolute' dating of mesolithic human activity at Star Carr, Yorkshire: new palaeoecological studies and identification of the (9600) BP radiocarbon 'plateau'. Proceedings of the Prehistoric Society 60:417-422

Es WA, Sarfatij van H, Woltering PJ (eds) (1988) Archeologie in Nederland. De rijkdom van het bodemarchief, Meulenhoff/ ROB, Amsterdam/Amersfoort

Faegri K, Iversen J (1989) Textbook of pollen analysis, fourth edition (revised byFaegri K., Kaland P.E. and Krzywinski K.). Wiley, Chichester

Geel van B (1978) A paleoecological study of Holocene peat bog sections in Germany and The Netherlands, based on the analysis of pollen, spores and macro- and microscopic remains of fungi, algae, cormophytes and animals. Rev Palaeobot Palynol 25:1-120

Geel van B (2001) Non-pollen palynomorphs. In:Smol JP, Birks HJB and Last WM (eds) Tracking environmental change using lake sediments; Volume 3:Terrestrial, algal and silicaceous indicators. Kluwer, Dordrecht, pp. 99-119

Geel van B, Bohncke SJP, Dee H (1981) A palaeoecological study of an upper Late Glacial and Holocene sequence from "De Borchert", The Netherlands. Rev Palaeobot Palynol 31:367448

Geel van B, Buurman J, Brinkkemper O, Schelvis J, Aptroot A, van Reenen GBA, Hakbijl T (2003) Environmental reconstruction of a Roman Period settlement site in Uitgeest (The Netherlands), with special reference to coprophilous fungi. J Archaeolg Sci 30:873-883

Geel van B, Coope GR, van der Hammen T (1989) Palaeoecology and stratigraphy of the Lateglacial type section at Usselo (The Netherlands). Rev Palaeobot Palynol 60:25-129

Geel van B, Grenfell HR (1996) Spores of Zygnemataceae (Chapter 7A). In: Jansonius J, McGregor DC. (eds), Palynology: principles and applications. Am Assoc Stratigr Palynol Found $1: 173-179$

Geel B, van Hallewas DP, Pals JP (1983) A Late Holocene deposit under the Westfriese Zeedijk near Enkhuizen (Prov. of N-
Holland, The Netherlands): palaeoecological and archaeological aspects. Rev Palaeobot Palynol 38:269-335

Gramsch B, Kloss K (1989) Excavations near Friesack: an Early Mesolithic marshland site in the northern plain of Central Europe. In: Bonsall C (ed) The Mesolithic in Europe. Donald Publishers Ltd, Edinburgh, pp. 313-324

Grimm EC (1992) TILIA and TILIA-GRAPH: pollen spreadsheet and graphics programs. 8th Int. Palynol. Congr. Aix-en-Provence, France, p. 56

Groenewoudt BJ, Deeben J, Geel van B, Lauwerier RCGM (2001) An early Mesolithic assemblage with faunal remains in a stream valley near Zutphen, The Netherlands. Archäologisches Korrespondenzblatt 31:329-348

Gronenborn D (1992) Inventarwerk zu mesolithischen Fundplätzen im Main-Mündungsgebiet. Ber. Kommision für Archäologische Landesforschung Hessen 1:35-37

Hahn J, Kind C-J, Steppan K (1993) Mesolithische Rentier-Jäger in Südwestdeutschland? Der mittelsteinzeitliche Freilandfundplatz Rottenburg "Siebenlinden I". Fundberichte Baden-Württemberg 18:29-52

Heinen M (1999) Ein mesolithischer Fundplatz auf der unteren Mittelterasse bei Hombroich, Kr. Neuss. Decheniana 38:48-55

Hicks S (1993) Pollen evidence of localized impact on the vegetation of northernmost Finland by hunter-gatherers. Veg Hist Archaeobot 2:137-144

Hoek WZ (1997) Palaeogeography of Lateglacial vegetations-Aspects of Lateglacial and Early Holocene vegetation, abiotic landscape, and climate in The Netherlands. Netherlands Geographical Studies, 230

Hoek WZ, Bohncke SJP (2002) Climatic and environmental events over the Last Termination, as recorded in The Netherlands; a review. Neth J Geosci 81:123-137

Innes JB, Blackford JJ (2003) The ecology of late Mesolithic woodland disturbances: Model testing with fungal spore assemblage data. J Archaeolg Sci 30:185-194

Jacobi RM, Tallis JH, Mellars PA (1976) The Southern Pennine Mesolithic and the ecological record. J Archaeolg Sci 3:307320

Janssen CR (1970) Problems in the recognition of plant communities in pollen diagrams. Vegetatio: Acta Geobotanica 22:187198

Kasse C (1995) Younger Dryas cooling and fluvial response (Maas River, The Netherlands). Geologie en Mijnbouw 74:251-256

Kasse C, Vandenberghe J, Bohncke SJP (1995) Climate change and fluvial dynamics of the Maas during the Late Weichselian and Early Holocene. Paläoklimaforschung/Palaeoclimate Research $14: 123-150$

Kind C-J (1997) Die mesolithische Freiland-Stratigraphie von Rottenburg "Siebenlinden 3" Archäologisches Korrespondenzblatt 27:13-32

Kloss K (1987a) Pollenanalysen zur Vegetationsgeschichte, Moorentwicklung und mesolithisch-neolitischen Besiedlung im Unteren Rhinluch bei Friesack, Bezirk Potsdam. Veröffentlichungen Museum für Ur- und Frühgeschichte Potsdam 21: $101-120$

Kloss K (1987b) Zur Umwelt mesolithischer Jäger und Sammler im Unteren Rhinluch bei Friesack. Versuch einer Rekonstruktion mit Hilfe von Moorstratigraphie und Pollenanalyse, Bezirk Potsdam. Veröffentlichungen Museum für Ur- und Frühgeschichte Potsdam 21:121-130

Kooistra MJ, Mulder JR, Spek Th (1999) Wat de bodem onthulde. Bodemkundig en micromorfologisch onderzoek aan een Mesolithische vindplaats op het rivierduin van Zutphen-Ooijerhoek. SC-DLO-Staring Centrum, internal report, Wageningen

Körber-Grohne U (1987) Nutzpflanzen in Deutschland. Kulturgeschichte und Biologie. Theiss, Stuttgart

Kubiak-Martens K (1999) The plant food component of the diet at the late Mesolithic (Ertebølle) settlement at Tybrind Vig, Denmark. Veg Hist Archaeobot 8:117-127 
Kubiak-Martens K (2002) New evidence for the use of root foods in pre-agrarian subsistence recovered from the late Mesolithic site at Halsskov, Denmark. Veg Hist Archaeobot 11:23-31

Krug JC, Scott JA (1994) The genus Bombardioidea. Can J Bot 72:(1302)-(1310)

Lange R, Twisk P, Winden van A, van Diepenbeek A (1994) Zoogdieren van West-Europa, Stichting Uitgeverij Koninklijke Nederlandse Natuurhistorische Vereniging, Utrecht

Lauwerier RCGM (1997) Laboratorium protocol archeozoölogieROB, Amersfoort

Litjens BEJ (1992) Wild zwijn, Sus scrofa. In: Broekhuizen S, Hoekstra B, Laar van V, Smeenk C, Thissen JBM (eds) Atlas van de Nederlandse zoogdieren, Stichting Uitgeverij Koninklijke Nederlandse Natuurhistorische Vereniging, Utrecht, pp. 195-199

Lundqvist N (1972) Nordic Sordariaceae s. lat, Symbolae Botanicae Upsaliensis 20:1-374

Marcenko E, Srdoc D, Golubic S, Pezdic J, Head MJ (1989) Carbon uptake in aquatic plants deduced from their natural ${ }^{13} \mathrm{C}$ and ${ }^{14} \mathrm{C}$ content. Radiocarbon 31:785-794

Meijden R, Weeda van der EJ, Adema FACB, Joncheere GJ (1983) Heukels/van der Meijden. Flora van Nederland. Wolters-Noordhoff, Groningen

Mellars P (1976) Fire Ecology, animal populations and man: a study of some ecological relationships in prehistory. Proc Prehist Soc 42:15-45

Mellars P, Dark P (1998) Star Carr in context: new archaeological an palaeoecological investigations at the Early Mesolithic site of Star Carr, North Yorkshire. McDonald Inst. Mon., Cambridge

Moore J (2000) Forest fire and human interaction in the early Holocene woodlands of Britain. Palaeogeography Palaeoclimatology Palaeoecology 164:125-137

Moore PD, Webb JA, Collinson ME (1991) Pollen analysis, 2nd edn. Blackwell, Oxford

Munk A (1957) Danish Pyrenomycetes. Danmarks Botanisk Arkiv $17: 1-491$

Neer W, Ervynck van A (1993) Archeologie en vis, Asse (Zellik). Instituut voor het Archeologisch Patrimonium

Nijssen H, Groot de SJ (1987) De vissen van Nederland. Stichting Uitgeverij Koninklijke Nederlandse Natuurhistorische Vereniging, Utrecht

Oberdorfer E (1994) Pflanzensoziologische Exkursionsflora. Ulmer, Stuttgart

O'Connell M, Molloy K, Geel van B (2001) Pollen analysis and 'other microfossils' (NPP) analyses (main profile and detailed investigations of laminae) An Loch Mór, Inis Oírr, W. Ireland. Final Report TIMECHS. EU, 4th Framework Programme 1-35

Pals JP, Geel van B, Delfos A (1980) Paleoecological studies in the Klokkeweel bog near Hoogkarspel (prov. of Noord Holland). Rev Palaeobot Palynol 30:371-418

Perry DW (1997) The archaeology of hunter-gatherers: plant use in the Dutch Mesolithic. Ann Arbor, UMI Microfilms

Perry DW (1999) Vegetative tissues from Mesolithic sites in the northern Netherlands. Curr Anthropol 40:231-237

Plicht van der J, Geel van B, Bohncke SJP, Bos JAA, Blaauw M, Speranza AOM, Muscheler R, Björck S (2004) The Preboreal climate reversal and a subsequent solar forced climate shift. J Quat Sci 19:263-269

Punt W et al. (1976-2003) The Northwest European Pollen Flora, vol I (1976); vol II (1980); vol III (1981); vol IV (1984); vol V (1988); vol VI (1991); vol VII (1995); vol VIII (2003). Elsevier Scientific Publishing Company, Amsterdam

Ralska-Jasiewiczowa M, Geel van B (1992). Early human disturbance of the natural environment recorded in annually laminated sediments of Lake Gosciaz, central Poland. Veg Hist Archaeobot 1:33-42

Renfrew JM (1973) Palaeoethnobotany. The prehistoric food plants of the Near East and Europe. Methuen, London

Rowley-Conwy P (1998) Faunal remains and antler artefacts. In: Mellars P, Dark P (eds), Star Carr in context: new archaeological an palaeoecological investigations at the Early
Mesolithic site of Star Carr, North Yorkshire. McDonald Inst. Mon., Cambridge, pp. 99-107

Runhaar J, Groen CLG, Meijden van der R, Stevens RAM (1987) Een nieuwe indeling in ecologische groepen binnen de Nederlandse flora. Gorteria 13:277-359

Schmitz H (1961) Pollenanalystische Untersuchungen in Hohen Viecheln am Schweriner See. In: Schuldt H (ed) Hohen Viecheln, ein mittelsteinzeitlicher Wohnplatz in Mecklenburg. Akademie Verlag, Berlin, pp. 14-38

Simmons IG (1993) Vegetation change during the Mesolithic in the British Isles: some amplifications. In: Chambers FM (ed) Climate change and human impact on the landscape. Chapman and Hall, London, pp. 109-118

Simmons IG, Turner J, Innes JB (1989) An application of fineresolution pollen analysis to later Mesolithic peats of an English upland. In: Bonsall C (ed) The Mesolithic in Europe. Donald Publishers Ltd, Edinburgh, pp. 206-217

Smith AG, Whittle A, Cloutman EW, Morgan LA (1989) Mesolithic and Neolithic activity and environmental impact on the south-east fen-edge in Cambridgeshire. Proc Prehist Soc $55: 207-249$

Spek Th (1996) Het Sallandse deklandschap. In: Spek Th, Zeiler FD, Raap E (eds) Van de Hunnepe tot de zee. De geschiedenis van het Waterschap Salland, IJsselacademie Kampen, Kampen, pp. $23-45$

Stockmarr J (1971) Tablets with spores used in absolute pollen analysis. Pollen and Spores 13:614-621

Street M (1989) Bedburg-Königshoven ein Wohnplatz am Niederrhein vor 10000 Jahren. Römisch-Germanisches Zentralmuseum, Mainz

Street M (1991) Bedburg-Königshoven: A Pre-Boreal Mesolithic site in the Lower Rhineland, Germany. In: Barton N, Roberts AJ, Roe DA (eds) The Late Glacial in north-west Europe:human adaptation and environmental change at the end of the Pleistocene. CBA Res Rep, 77:256-270

Stuiver M, Reimer PJ (1993) Extended 14C database and revised CALIB radiocarbon calibration program, Radiocarbon 35:215230

Stuiver M, Reimer PJ, Bard E, Beck JW, Burr GS, Hughen KA, Kromer B, McCormac FG, Plicht van der J, Spurk M (1998) INTCAL98 Radiocarbon age calibration, 24,000-0 cal BP. Radiocarbon 40:1041-1083

Törnqvist TE, Jong de AFM, Oosterbaan WA, Borg van der K (1992) Accurate dating of organic deposits by $\mathrm{AMS}^{14} \mathrm{C}$ measurement of macrofossils. Radiocarbon 34:566-577

Urz R (2000) Begraben unter Auelehm: Frühmesolithische Siedlungsspuren im mittleren Lahntal. Archäologisches Korrespondenzblatt 30:33-43

Vera FWM (2000) Grazing ecology and forest history. CABI Publ., Wallingford

Verhagen M (1989) De beer in de Nederlandse pre- en protohistorie. Cranium 3:65-71

Verneau S (1999) Een Mesolithisch jachtkamp te Zutphen. (8000) jaar voor Christus: jagers-verzamelaars in de Ooyerhoek. Lithos Rapport 1 (Zutphen)

Verstrael TJ (1988) De verspreiding van de bruine beer Ursus arctos in Europe. Lutra 31:44-61

Waterbolk HT (1999) De mens in het Preboreale, Boreale en Atlantische bos. Paleo-Aktueel 10:68-73

Welinder S (1989) Mesolithic Forest Clearance in Scandinavia. In: Bonsall C (ed), The Mesolithic in Europe. Donald Publishers Ltd, Edinburgh, pp 362-366

Wijmstra TA, Vin de A (1971) De Dinkel canal section. In: Hammen van der T, Wijmstra TA (eds), Upper Quaternary of the Dinkel Valley. Mededelingen Rijks Geologische Dienst Nieuwe Serie 22:101-129

Zagwijn W (1986). Nederland in het Holoceen, Staatsuitgeverij, 's Gravenhage

Zvelebil M (1994) Plant use in the Mesolithic and its role in the transition to farming. Proc Prehist Soc 60:35-74 